\title{
IbM Guru: Pelatihan dan Pendampingan Pengembangan Buku Ajar Literasi Matematika dan Bahasa
}

\author{
Fatimatul Khikmiyah', Candra Hadi Asmara ${ }^{2}$, Afakhrul Masub Bakhtiar ${ }^{3}$ \\ 1 Prodi Pendidikan Matematika, Universitas Muhammadiyah Gresik, Indonesia \\ 2 Prodi Pendidikan Bahasa Inggris, Universitas Muhammadiyah Gresik, Indonesia \\ ${ }_{3}^{3}$ Prodi Pendidikan Guru Sekolah Dasar, Universitas Muhammadiyah Gresik, Indonesia
}

\begin{abstract}
Abstrak
Khikmiyah (2016) menunjukkan bahwa pengetahuan yang dimiliki oleh para guru khususnya guru matematika tentang literasi sangat rendah. Meskipun demikian, sebagian besar guru menyatakan bahwa kemampuan literasi memiliki peranan penting bagi peserta didik. Selain itu, referensi berbahasa Indonesia yang digunakan untuk mendukung tercapainya literasi sangat terbatas. Agar siswa memiliki kemampuan literasi yang baik maka kemampuan ini harus diasah dan dilatih sejak dini. Salah satu cara paling efektif yang dapat dilakukan untuk melatih literasi siswa sejak dini yaitu melalui guru. Program yang ditawarkan dalam kegiatan pengabdian IbM ini adalah menyelenggarakan pelatihan dan pendampingan buku ajar literasi matematika dan bahasa untuk guru SD/MI. Tujuan jangka panjang dari kegiatan ini adalah menyebarluaskan literasi matematika dan bahasa, peningkatan pengetahuan dan kemampuan literasi guru dan siswa di sekolah dasar dan menengah serta tersedianya buku ajar literasi untuk siswa sekolah dasar dan menengah. Adapun target khusus yang ingin dicapai dalam kegiatan pengabdian ini adalah tersedianya buku ajar literasi matematika dan bahasa untuk siswa SD/MI. Hasil dari kegiatan ini yaitu; (1) Buku ajar literasi matematika dan Bahasa untuk Siswa kelas 5 SD/MI (2)Meningkatnya pengetahuan dan pemahaman guru tentang literasi, (3).Meningkatnya kesadaran guru tentang pentingnya literasi bagi peserta didik, (4).Meningkatnya pengetahuan dan pemahaman guru tentang model penelitian pengembangan khususnya model ADDIE, (5). Meningkatnya pengetahuan dan pemahaman guru tentang teknik penulisan buku.
\end{abstract}

\author{
Keywords: \\ Pelatihan, Buku Ajar, \\ Literasi Matematika \\ Literasi Bahasa
}

\section{Pendahuluan}

Literasi merupakan salah satu unsur yang dinilai dalam Programme for International Student Assessment( PISA). Literasi dalam PISA meliputi literasi matematika, literasi sains, literasi keuangan, literasi bahasa. Sampai tahun 2012 peringkat Indonesia dalam penilaian PISA masih jauh dari harapan. Literasi bahasa merupakan domain utama dalam penilaian PISA sejak siklus PISA yang pertama pada tahun 2000. Literasi bahasa tidak hanya diartikan sebagai membaca dengan lantang tetapi lebih dari itu mencakup hal yang lebih luas dan lebih mendalam. Literasi bahasa mencakup kemampuan kognitif yang luas mulai dari pengkodean dasar, pengetahuan terhadap kata, tata bahasa, linguistik, struktur text dan pengetahuan tentang dunia.

Literasi matematika dalam kerangka PISA Matematika 2012 didefinisikan sebagai kemampuan individu untuk merumuskan, menggunakan dan menafsirkan matematika dalam berbagai konteks.Termasuk kemampuan melakukan penalaran secara matematis dan menggunakan konsep, prosedur, fakta, sebagai alat untuk mendeskripsikan, menjelaskan serta memprediksi suatu fenomena atau kejadian.Literasi matematis dapat membantu individu untuk mengenal peran matematika di dunia nyata dan sebagai dasar pertimbangan dan penentuan keputusan yang dibutuhkan oleh masyarakat (OECD, 2013).

Hasil analisa kebutuhan yang dilakukan oleh Khikmiyah(2016) sebagai bagian dari proses pengembangan buku ajar literasi matematika untuk siswa SMP yang didanai oleh DIKTI dalam skema Penelitian Dosen Pemula (PDP) pada tahun anggaran 2016 menunjukkan bahwa masih banyak guru yang tidak memiliki pengetahuan yang memadai tentang literasi peserta didiknya. Data ini diambil dengan 
sampel sebanyak 32 guru dari 12 (dua belas) sekolah SMP dan MTs negeri dan swasta yang tersebar di kabupaten Gresik. Pengetahuan tentang literasi pada umumnya diperoleh dari internet dan mulai dicari atau dibaca ketika diminta untuk mengisi angket. Literasi nampaknya belum menjadi perhatian bagi para guru meskipun di dunia pendidikan global dan internasional literasi merupakan bahan perbincangan populer. Meskipun demikian semua guru yang tahu tentang literasi berpendapat bahwa kemampuan literasi penting bagi peserta didik baik di sekolah maupun di kehidupannya.

Pengembangan buku ajar literasi matematika yang telah dilakukan tim pengusul ditujukan bagi siswa SMP. Meskipun demikian, telah diketahui bersama bahwa dasar dari pengembangan kemampuan siswa adalah pendidikannya di Sekolah Dasar(SD). Jika sejak dini siswa telah diperkenalkan dengan literasi, dilatih dan dibina secara berkesinambungan maka hasil yang dicapai akan lebih maksimal karena pada dasarnya pendidikan merupakan sebuah proses panjang. Salah satu cara paling efektif yang bisa dilakukan yaitu melalui guru. Lebih lanjut dijelaskan oleh Khikmiyah(2016) bahwa referensi literasi berbahasa Indonesia yang dapat digunakan oleh guru untuk mendukung tercapainya literasi peserta didik sangat terbatas.

Program Pengabdian Masyarakat yang diusulkan ini dilaksanakan dengan subyek seluruh guru di MI Darul Ulum dan MI Al Azhar. Kedua mitra terletak di Desa Petis Benem yang berjarak sekitar 16 km dari Universitas Muhammadiyah Gresik. Kedua sekolah ini telah terakreditasi "A".

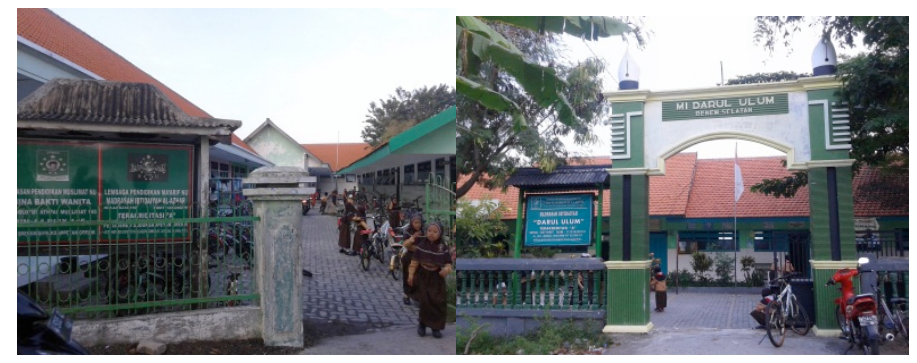

Gambar 1. MI Al Azhar dan MI Darul Ulum

Dalam proses pembelajaran, guru-guru di sekolah ini menggunakan buku paket yang disediakan oleh pemerintah yaitu Buku Sekolah Elektronika (BSE) sedangkan tugas-tugas yang diberikan kepada siswa seluruhnya diambil dari Lembar Kerja Siswa(LKS) yang dibeli dari penerbit. Dengan demikian LKS lebih mendominasi dalam pembelajaran jika dibandingkan dengan buku BSE. Mengambil sampel dari LKS matematika kelas VI(enam) didapatkan fakta sebagai berikut; terdapat 8 bab untuk 2(dua) semester, rangkuman materi disajikan pada bagian awal kemudian dilanjutkan dengan contoh-contoh soal. Setelah itu disajikan soal-soal latihan untuk siswa. Pada akhir Standar Kompetensi diberikan soal uji kompetensi yang berisi 20 soal pilihan ganda, 10 soal isian singkat dan 5 soal uraian panjang. Semua LKS berisi sampai dengan 160 halaman.

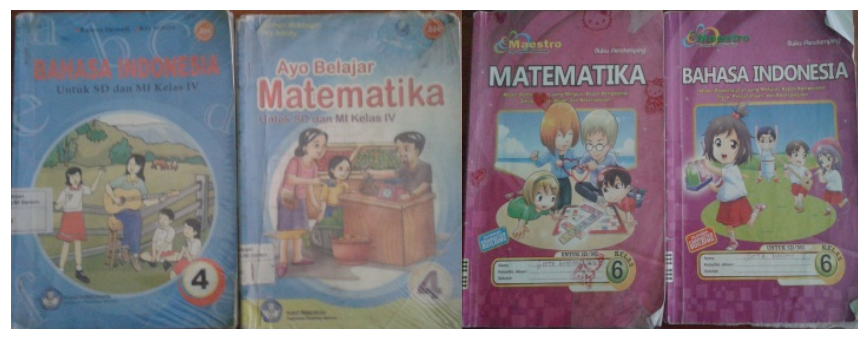

Gambar 2. Buku dan LKS yang digunakan oleh guru

Dalam literasi matematika PISA, soal-soal yang digunakan memuat 4(empat) macam konteks yaitu konteks pribadi(25\%), pekerjaan(25\%), konteks sosial(25\%) dan konteks keilmuan(25\%). Sedangkan kemampuan siswa dalam PISA dibagi menjadi enam level (tingkatan), level 1 yang paling rendah dan level 6 sebagai tingkat pencapaian yang paling tinggi( Hayat, 2010). Analisa LKS yang digunakan oleh guru menunjukkan bahwa situasi yang digunakan pribadi(75\%), konteks sosial(10\%), konteks keilmuan(20\%) dan tidak ditemukan konteks pekerjaan. Jika dilihat dari level kemampuan peserta didik, maka soal-soal yang disajikan hanya sampai pada level 2(dua) dalam penilaian PISA dengan komposisi $25 \%$ sedangkan sisanya hanya berlevel 1(satu). 


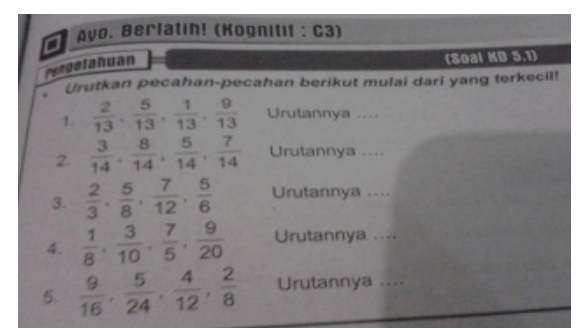

Gambar 3. Contoh soal matematika dalam LKS

Observasi yang dilakukan terhadap LKS Bahasa Indonesia tidak jauh berbeda dengan LKS matematika. Dalam LKS Bahasa Indonesia terdapat 10 Bab untuk 2(dua) semester yang ditulis dalam 160 halaman. Setiap bab terdiri dari 4(empat) sub bab. Rangkuman materi disajikan pada bagian awal subbab kemudian dilanjutkan dengan menjawab soal dengan jawaban yang sudah tersedia dalam teks, begitu seterusnya sampai dengan sub bab yang ke-4. Pada akhir Standar Kompetensi diberikan soal uji kompetensi yang berisi 30 soal pilihan ganda, dan 10 soal isian singkat.

Dalam Literasi bahasa yang dinilai oleh PISA, situasi yang digunakan dalam membaca teks meliputi pribadi(36\%), pendidikan(33\%), pekerjaan(20\%) dan situasi umum/publik(11\%). Selain situasinya dalam PISA juga dibedakan antara membaca buku teks dengan membaca digital sedangkan dalam LKS yang digunakan oleh guru tersebut disajikan situasi pribadi(10\%), pendidikan(10\%), pekerjaan(40\%) dan situasi umum/publik(40\%). Berikut contoh soal literasi bahasa PISA yang berkaitan dengan digital.

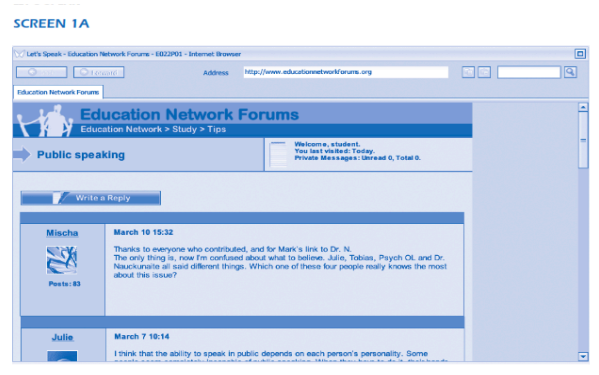

Gambar 4. Soal literasi bahasa PISA

Soal tersebut berkaitan dengan forum diskusi pendidikan yang dilakukan secara online. Jangankan di buku bahasa untuk SD/MI, di buku SMP pun mungkin kita tidak bisa menemui pembahasan tentang ini.

Melihat perbedaan yang sangat signifikan antara isi penilaian PISA baik dalam literasi bahasa maupun matematika dengan buku ajar yang digunakan oleh guru dalam proses pembelajaran maka tidak mengherankan jika nilai siswa kita di penilaian PISA selalu berada dikategori terendah(OECD, 2013: 19). Kondisi ini mungkin tidak hanya terjadi di MI Darul Ulum dan MI Al Azhar tetapi juga di sebagian besar sekolah di Indonesia. Dengan berpedoman pada buku paket dan LKS penerbit, maka bisa dikatakan bahwa motivasi dan keterampilan guru dalam mengembangkan materi yang diajarkan masih rendah.

Akibat lain dari penggunaan LKS penerbit ini adalah guru-guru tidak mempersiapkan secara detail proses pembelajaran dalam kelas. Matematika seringkali disajikan secara mekanistik dengan mengajarkan matematika sebagai produk jadi, mentransfer konsep-konsep yang abstrak kepada peserta didik padahal bagi anak usia SD/MI hal ini bukanlah perkara mudah.

Buku ajar literasi Matematika dan bahasa sengaja dipilih untuk dikembangkan karena di dua sekolah mitra guru mata pelajaran ini memiliki latar belakang pendidikan yang sesuai yaitu S1 Pendidikan matematika dan S1 pendidikan bahasa dan sastra Indonesia. Mereka juga memiliki kemauan untuk mengembangkan diri dengan berkomitmen menjadi leader (ketua) di kelompok pengembang buku ajar yang akan dibentuk dalam pelaksanaan pengabdian IbM ini. Oleh karena itu kegiatan pengabdian Iptek bagi Masyarakat ini diberi judul IbM guru: Pelatihan dan Pendampingan guru dalam mengembangakan Buku Ajar Literasi Matematika dan Bahasa.

\section{Metode}

Untuk menyelesaikan permasalahan yang telah dipaparkan pada bagian sebelumnya, maka berikut ini akan ditampilkan tahapan penyelesaian permasalahan sebagai berikut: 


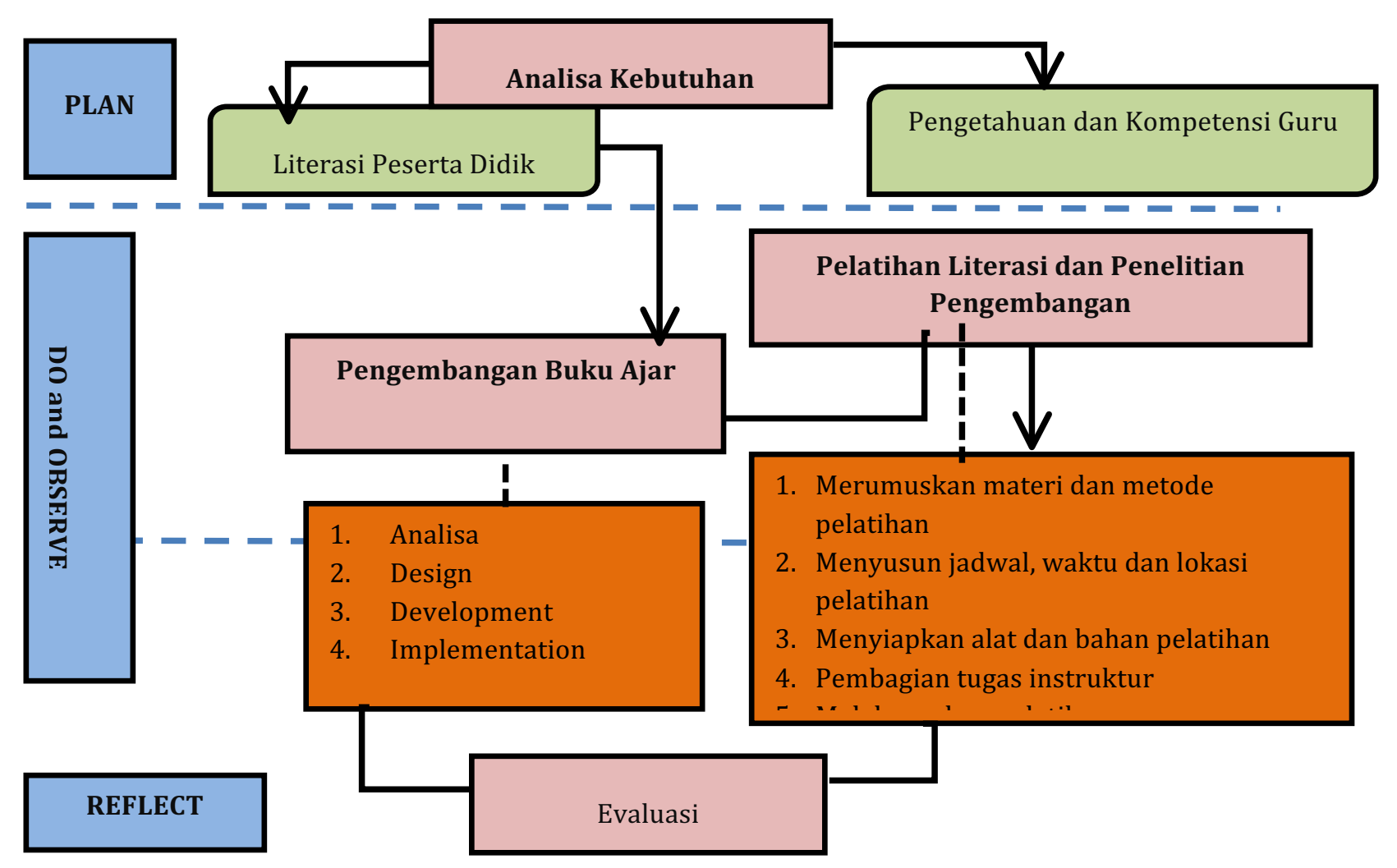

Keterangan

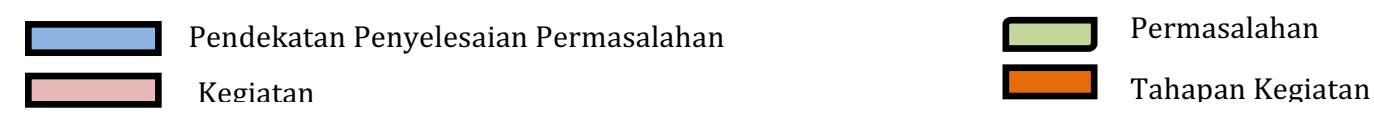

Gambar 5. Tahapan Penyelesaian Permasalahan

Kegiatan yang direncanakan sebagai penyelesaian atas permasalahan secara rinci dijelaskan sebagai berikut:

1. Analisa Kebutuhan

Kegiatan ini bertujuan untuk melihat secara detail pengetahuan guru terhadap literasi, tahapan kemampuan literasi peserta didik, penelitian pengembangan dan pengalaman yang telah dimiliki berkaitan dengan penelitian perkembangan tersebut. Kegiatan ini dilakukan melalui penyebaran angket kepada guru yang dilanjutkan dengan memilih beberapa guru untuk penggalian informasi lebih dalam melalui wawancara.

2. Pelatihan Literasi dan Penelitian Pengembangan

Pelatihan yang diberikan kepada mitra mempunyai tujuan untuk memberikan tambahan pengetahuan tentang literasi, tahapan kemampuan literasi peserta didik, model soal-soal literasi, dan penelitian pengembangan. Pelatihan secara keseluruhan direncanakan dilaksanakan selama 4 kali pertemuan dimana setiap pertemuan dilaksanakan selama 4 jam, namun apabila masih diperlukan dapat dilakukan penambahan waktu.

Dalam kerangka PISA tersebut literasi matematika didefinisikan sebagai kemampuan seseorang untuk memformulasikan, menerapkan dan menginterpretasikan matematika dalam berbagai konteks. Literasi ini mencakup bernalar secara matematis dan menggunakan konsep, prosedur, fakta dan alat bantu lain untuk menjelaskan dan meprediksi fenomena. Selain itu, literasi juga membantu seseorang untuk mengenali peranan matematika. Sedangkan literasi bahasa didefinisikan sebagai: 1).Pengetahuan terhadap bahasa dan menggunakannya untuk mengidentifikasi pertanyaan, memperoleh pengetahuan yang baru, menjelaskan fenomena ilmiah dan menggambarkan kesimpulan tentang isu-isu bahasa yang terkait berdasarkan bukti, 2).Pemahaman terhadap 
karakteristik bahasa sebagai pengetahuan dan hasil penyelidikan manusia, 3).sadar bagaimana bahasa dan teknologi membentuk materi, intelektual dan budaya, 4). Kemauan untuk terlibat dalam isu-isu yang berkaitan dengan bahasa. Tahapan literasi seseorang dibedakan menjadi 6(enam) tingkatan/level yaitu 1(satu) untuk tahap terendah dan 6(enam) untuk tahap tertinggi.

Berdasarkan penjelasan di atas, maka materi yang akan disajikan dalam pelatihan pengembangan buku ajar tersebut adalah: a) Literasi; definisi, macam-macam literasi,tahapan kemampuan literasi peserta didik, b) Model soal-soal literasi, c) Penelitian Pengembangan, d) Teknik Penulisan Buku Ajar.

3. Pengembangan Buku Ajar

Buku ajar adalah bahan-bahan atau materi pembelajaran yang disusun secara sistematis yang digunakan guru dan siswa dalam proses pembelajaran (Pannen dan Purwanto, 2001). Proses pengembangan buku ajar dilakukan berdasarkan penelitian pengembangan model ADDIE yang merupakan singkatan dari Analysis, Design, Development, Implementation, and Evaluation. Prosedur pengembangan(Development) yang dilakukan terdiri atas beberapa tahap. Tahap-tahap pengembangan dipaparkan dalam uraian berikut ini.

a.Tahap I menentukan level materi yang akan digunakan pada buku ajar.

b. Tahap II mengidentifikasi kompetensi dasar. Melakukan analisis pembelajaran, mengidentifikasi perilaku awal dan karakteristik peserta didik, menulis indikator, dan mengembangkan butirbutir tes acuan patokan.

c. Tahap III mengembangkan strategi pembelajaran dan mengembangkan dan/atau memilih materi pembelajaran. Dalam tahap ini disusun strategi pembelajaran untuk mencapai tujuan yang telah ditetapkan. Kegiatan ini meliputi aktivitas prapembelajaran, penyajian informasi dan umpan balik, penilaian, dan kegiatan tindak lanjut.

d. Tahap IV penyusunan dan penulisan buku ajar, Buku ajar mempunyai komponen pembelajaran yang meliputi: (1) judul bab dan konsep-konsep kunci, (2) petunjuk, (3) kerangka isi, (4) kompetensi dasar, (5) indikator, (6) materi, (7) tugas dan latihan, (8) rangkuman, (10) tes akhir bab, dan (11) sumber pendukung. Panduan siswa berisi petunjuk bagi siswa dalam memanfaatkan buku ajar dalam pembelajaran.

e.Tahap V mendesain dan melakukan evaluasi formatif kemudian merevisi produk pengembangan, Evaluasi formatif meliputi uji ahli isi, uji ahli desain dan media pembelajaran, uji coba perorangan, uji coba kelompok kecil, dan uji coba lapangan. Data-data yang diperoleh dari masing-masing kegiatan uji coba tersebut dianalisis dan hasil analisis digunakan untuk merevisi produk pengembangan.

4. Evaluasi

Evaluasi dilakukan untuk melihat apakah buku ajar yang telah dikembangkan oleh guru sesuai dengan harapan awal yang ditetapkan dalam hal ini mampu mengembangkan literasi matematika dan bahasa peserta didik. Evaluasi meliputi evaluasi formatif dan evaluasi sumatif. Evaluasi formatif terjadi pada setiap tahap untuk penyempurnaan buku ajar sedangkan evaluasi sumatif digunakan untuk mengetahui pengaruhnya terhadap kualitas pembelajaran.

\section{Hasil dan Pembahasan}

Hasil dan Luaran yang dicapai pada kegiatan pengabdian ini dijabarkan berdasarkan tahapan kegiatan yang dilakukan yaitu sebagai berikut :

\section{A. Kegiatan pelatihan literasi dan penelitian pengembangan}

Pada kegiatan ini para guru di sekolah mitra mendapatkan materi tentang 1). Literasi bahasa, 2). Literasi matematika, 3). Definisi, pentingnya penelitian pengembangan dalam dunia pendidikan, serta model dan tahapan penelitian pengembangan. Kegiatan tersebut diikuti oleh seluruh guru di MI Darul Ulum dan MI Al Azhar yang berjumlah 25 orang. Dalam kegiatan tersebut peserta khususnya guru matematika dan bahasa antusias menyimak paparan materi yang disampaikan oleh nara sumber karena selama ini mereka hanya mendengar istilah literasi dan menganggap literasi sekedar menerapkan kebiasaan membaca sebelum pembelajaran di mulai. Selain itu, tim pengabdi juga berbagi (sharing) pengalaman mengembangkan buku ajar kepada para peserta dengan tujuan memberikan motivasi kepada para guru bahwa mengembangkan buku ajar tidaklah sesulit yang mereka bayangkan. Dengan pengalaman mengajar yang dimiliki oleh para guru ditambah dengan niat dan ketekunan maka setiap guru pada dasarhnya mampu mengembangkan buku ajar untuk meningkatkan kualitas pembelajaran mereka.

\section{B. Kegiatan Pengembangan Buku Ajar}

\section{Analisis Kebutuhan}


Analisis dilakukan terhadap buku Tematik Terpadu yang terdiri dari buku guru dan buku siswa yang diterbitkan oleh Kementrian Pendidikan dan Kebudayaan Republik Indonesia tahun 2014. Buku ini menggunakan kurikulum 2013 sehingga silabus telah disiapkan oleh pemerintah. Sebelum kegiatan analisis dimulai, tim pengabdi menyiapkan rangkuman Standar Kompetensi, Kompetensi Dasar dan Indikator yang tertera dalam buku guru. Rangkuman ini disiapkan dalam bentuk cetak (hard copy) dan file (soft copy) sehingga memudahkan bagi guru untuk berdiskusi dan menuliskan hasil diskusi dalam bentuk file. Berikutnya, analisis isi dan kompetensi didasarkan pada standar kompetensi, kompetensi dasar dan indikator buku tematik yang digunakan oleh guru. Selain itu juga mengacu pada permasalahan yang disajikan dalam PISA (Programme International for Students Assessment). Selama proses analisis, tim pengabdi mendampingi kelompok secara bergantian. Memberikan arahan dan masukan serta meminta peserta menuliskan hasil analisis kelompoknya dalam bentuk softcopy.

2. Tahap Perancangan (Desain).

Tahap ini meliputi tiga kegiatan, yaitu:

a) Mengembangkan Indikator dan Merumuskan Tujuan Pembelajaran

Berdasarkan pada analisis kebutuhan yang diimplementasikan pada tahap sebelumnya, maka dirumuskan indikator yang diturunkan menjadi tujuan pembelajaran yang diharapkan dapat dicapai oleh peserta didik setelah mempelajari suatu materi atau konsep tertentu.

b) Menyusun Tes

Pada kegiatan ini, tim pengembang menyusun tes hasil belajar yang akan digunakan oleh guru untuk mengukur ketercapaian tujuan pembelajaran yang telah ditetapkan pada bagian sebelumnya. Soal tes setiap tema terdiri dari 5(lima) soal uraian dengan rincian 2(dua) soal untuk level 1 dan masing-masing 1(satu) soal untuk level 2(dua) dan level 3(tiga).

c) Menentukan Strategi/Model Pembelajaran yang Tepat

Buku tematik dengan kurikulum 2013 sangat sesuai diterapkan dengan strategi/model pembelajaran dengan pendekatan konstruktivisme. Beberapa metode yang cocok untuk diterapkan di tingkat MI/SD misalnya Penemuan Terbimbing (Guided Discovery Learning), Metode Penemuan(Inkuiry Learning), Pendidikan Matematika Realistik, dan metode Pembelajaran Berbasis Masalah (Problem Based Learning). Dari ketiga model pembelajaran tersebut, tim pengabdi dan tim pengembang menetapkan model pembelajaran berbasis masalah

3. Tahap Pengembangan

Tahap ini merupakan proses mewujudkan rancangan awal yang telah disusun pada tahap sebelumnya. Pada tahap ini guru mengembangkan buku ajar dengan menuliskan idenya pada kertas folio bergaris. Selanjutnya guru-guru berdiskusi dengan tim dosen pengabdi. Diskusi dalam tim pengembang buku literasi matematika misalnya berkaitan dengan kesesuaian antara kompetensi dasar dan tujuan pembelajaran dengan permasalahan yang disajikan dalam diskusi kelompok, kata kunci, gambar yang digunakan untuk mengilustrasikan permasalahan, tingkat kesulitan soal yang disajikan dan banyaknya soal yang disajikan dalam setiap bab. Berikut ini adalah gambar tim pengembang buku ajar literasi matematika pada saat diskusi pengembangan buku.

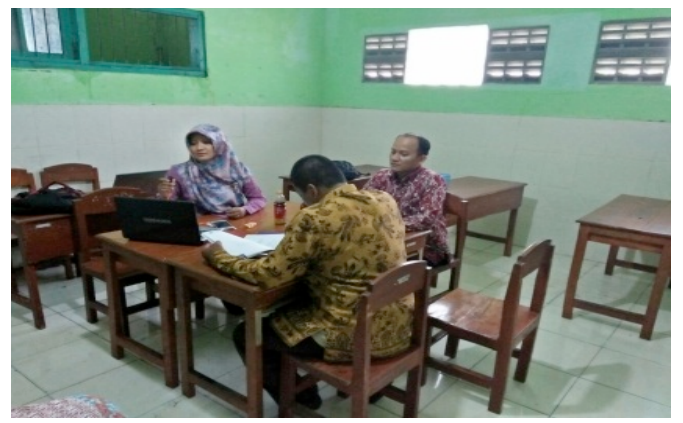

Gambar 2. Tim pengembang Buku Literasi Matematika sedang berdiskusi

Diskusi dalam tim pengembang buku literasi bahasa antara lain berkaitan dengan bahan bacaan yang ditampilkan dalam setiap tema, gambar ilustrasi, serta model soal yang digunakan dalam pembelajaran. Berikut ini adalah gambar tim pengembang buku ajar literasi matematika pada saat diskusi pengembangan buku 


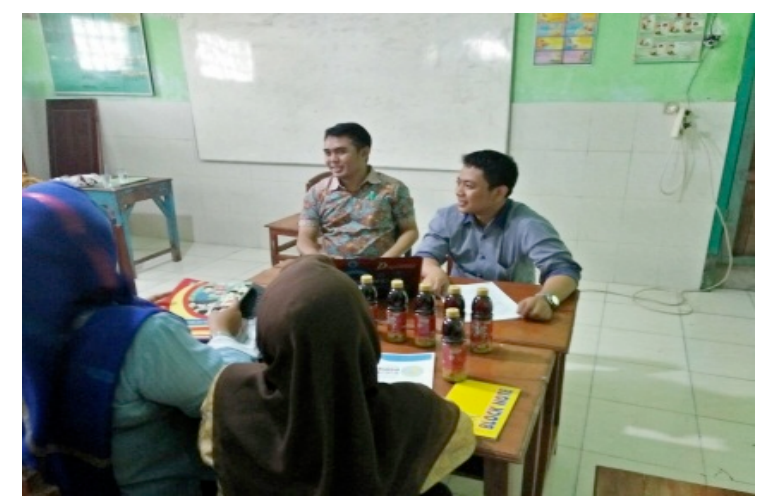

Gambar 3. Tim pengembang Buku Literasi Bahasa sedang berdiskusi

Setelah mengembangkan buku ajar, mahasiswa yang terlibat dalam kegiatan pengabdian membantu membuat desain cover, desain cover dan menata tampilan (lay out) buku. Setelah itu, buku draft 1 diserahkan kepada ahli materi dan ahli desain untuk divalidasi. Validasi dilaksanakan dengan memberikan penilaian pada angket tertutup.Selain itu, di bagian akhir instrumen diberikan tempat untuk para validator memberikan saran.

Untuk buku ajar literasi matematika, validator materi pertama memberikan nilai 80\% sedangkan validator materi kedua memberikan nilai $81,67 \%$ sehingga nilai rata-rata dari kedua validator adalah $80,835 \%$ dan berada pada kategori valid. Validator ahli desain pertama memberikan nilai $82,86 \%$ sedangkan validator desain kedua memberikan nilai $85,71 \%$ sehingga nilai rata-rata dari kedua validator adalah $84,285 \%$ dan berada pada kategori valid. Dari penilaian keempat validator ini maka buku ajar literasi matematika dapat digunakan pada tahap berikutnya.

Untuk buku ajar literasi Bahasa Indonesia, Validasi buku ajar literasi bahasa dilakukan oleh Nataria Wahyuning S, M. Pd dan Iqnatia Alfiansyah, M. Pd. Validator materi pertama memberikan nilai $80 \%$ sedangkan validator materi kedua memberikan nilai 78,33\% sehingga nilai rata-rata dari kedua validator adalah 80,835\% dan berada pada kategori valid. Validator ahli desain buku ajar Literasi Bahasa Indonesia sama dengan validator ahli desain untuk buku matematika. Validator pertama memberikan nilai 74,285\% sedangkan validator desain kedua memberikan nilai $74,285 \%$ \% sehingga nilai rata-rata dari kedua validator adalah $74,285 \%$ \% dan berada pada kategori valid. Dari penilaian keempat validator ini maka buku ajar literasi bahasa dapat digunakan pada tahap berikutnya. Selain angket tertutup, ahli materi juga memberikan saran atas buku ajar draf 1 . Secara berturut-turut di bawah ini adalah saran dari para ahli serta upaya tindak lanjut untuk perbaikan buku ajar literasi matematika dan bahasa.

Tabel 1. Saran dari ahli untuk buku ajar literasi matematika serta upaya tindak lanjut

\begin{tabular}{|c|c|c|}
\hline VALIDATOR & SARAN & UPAYA TINDAK LANJUT \\
\hline \multirow[t]{2}{*}{ Ahli Materi } & $\begin{array}{l}\text { Sub tema } 6 \text {, kurang sesuai dengan } \\
\text { materi }\end{array}$ & $\begin{array}{l}\text { Tema } 6 \text { menyesuaikan dengan } \\
\text { kurikulum 2013, sehingga tidak } \\
\text { dapat dirubah }\end{array}$ \\
\hline & $\begin{array}{l}\text { Perhatikan penulisan tanda baca, } \\
\text { perintah pada soal bahasanya } \\
\text { disesuaikan dengan } \\
\text { perkembangan anak }\end{array}$ & $\begin{array}{l}\checkmark \\
\checkmark \text { Penulisan tanda baca } \\
\text { diperbaiki } \\
\checkmark \quad \text { Perintah pada soal diperbaiki }\end{array}$ \\
\hline \multirow[t]{2}{*}{ Ahli Desain } & $\begin{array}{l}\text { Sudah bagus, namun ikon pada cover } \\
\text { mungkin bisa dibuat file vectornya } \\
\text { sehingga untuk media cetak besar } \\
\text { gambar tidak terlihat pecah }\end{array}$ & $\begin{array}{l}\text { Mengubah ikon vektor menjadi } \\
\text { vektor }\end{array}$ \\
\hline & $\begin{array}{l}\text { Print out cover depan dan isi sudah } \\
\text { menarik dan sesuai tinggal cover } \\
\text { belakang yang perlu diperbaiki } \\
\text { kualitas cetak atau perpaduan } \\
\text { warnanya }\end{array}$ & File di print melalui Corel Draw \\
\hline
\end{tabular}
berikut:

Adapun saran dari ahli untuk pengembangan buku ajar literasi bahasa adalah sebagai 
Tabel 2. Saran dari ahli untuk buku ajar literasi Bahasa serta upaya tindak lanjut

\begin{tabular}{|c|c|c|}
\hline VALIDATOR & SARAN & UPAYA TINDAK LANJUT \\
\hline \multirow[t]{2}{*}{ Ahli Materi } & $\begin{array}{l}\text { Pada tujuan pembelajaran } \\
\text { sebaiknya ditambahkan (degree) } \\
\text { tingkatan/ level capaian, alangkah } \\
\text { lebih baik ditambahkan halaman, } \\
\text { gambar-gambar sudah sesuai } \\
\text { dengan karakter pembelajaran di } \\
\text { SD dan sudah cukup kuantitasnya }\end{array}$ & Memberi halaman \\
\hline & $\begin{array}{l}\text { Sangat bagus, namun untuk } \\
\text { kejelasan petunjuk pada tiap BAB } \\
\text { harap diperhatikan lagi. Gunakan } \\
\text { bahasa yang mudah dipahami anak }\end{array}$ & Memperbaiki bahasa \\
\hline \multirow[t]{2}{*}{ Ahli Desain } & $\begin{array}{l}\text { Untuk siswa kelas V SD mungkin } \\
\text { keterkaitan dengan model gambar } \\
\text { pabrik kurang. Mungkin bisa } \\
\text { memakai foto HI (Human Interest) } \\
\text { dengan adanya visual personal } \\
\text { untuk warna judul terlalu banyak } \\
\text { warna sehingga sulit dipadukan } \\
\text { dengan warna cover }\end{array}$ & $\begin{array}{l}\text { Mempertimbangkan desain yang } \\
\text { baru }\end{array}$ \\
\hline & $\begin{array}{l}\text { Gambar-gambar serta font untuk isi } \\
\text { buku sudah baik, hanya saja } \\
\text { keterpaduan warna kurang cerah/ } \\
\text { menarik untuk memotivasi siswa } \\
\text { SD/MI. Cover sangat abstrak } \\
\text { gambarnya. }\end{array}$ & Menyesuaikan warna \\
\hline
\end{tabular}

Saran ini kemudian ditindaklanjuti dan setelah dilakukan perbaikan disebut sebagai buku ajar draft 2 dan buku inilah yang digunakan dalam tahap implementasi.

4. Tahap Implementasi

Pada tahap ini buku ajar yang telah dikembangkan diimplementasikan dalam kelas. Buku Ajar Literasi Matematika diterapkan di MI Darul Ulum dengan 17(tujuh belas) peserta didik sedangkan buku Ajar Literasi Bahasa diterapkan di MI Al Azhar dengan 12(dua belas) peserta didik. Setelah implementasi, tim pengabdi dan guru berdiskusi tentang kelebihan dan kekurangan dari buku yang sudah dikembangkan.

Dalam proses impelementasi, tim juga melakukan tanya jawab dengan peserta didik untuk mendapatkan saran dan komentar terhadap buku ajar. Beberapa komentar yang diberikan peserta didik yaitu soal-soal yang disajikan dalam buku ajar tidak biasa karena semua

\section{Evaluasi}

memuat soal cerita dan dalam satu soal ada yang memuat beberapa materi sekaligus.

Evaluasi dalam kegiatan IbM dilaksanakan untuk mengevaluasi keterlibatan guru dalam pelatihan, pelaksanaan dan hasil akhir pengembangan buku ajar. Tabel di bawah ini menyajikan kegiatan evaluasi dan persentase keberhasilan kegiatan.

Tabel 3. Evaluasi dan Persentase kegiatan Pengabdian skema Iptek bagi Masyarakat(IbM)

\begin{tabular}{|c|c|c|c|c|}
\hline NO & KEGIATAN & INDIKATOR & $\begin{array}{c}\text { TOLOK UKUR } \\
\text { KEBERHASILAN }\end{array}$ & KETERCAPAIAN \\
\hline 1 & $\begin{array}{l}\text { Pelatihan Literasi } \\
\text { dan Penelitian } \\
\text { Pengembangan }\end{array}$ & $\begin{array}{l}\text { Jumlah peserta } \\
\text { Pengetahuan guru tentang } \\
\text { penelitian pengembangan } \\
\text { Pengetahuan guru tentang } \\
\text { literasi peserta didik }\end{array}$ & $70 \%$ & $\begin{array}{c}100 \% \\
75,86 \% \\
86,2 \%\end{array}$ \\
\hline 2 & Pengembangan Buku & Banyaknya buku ajar yang & 1(satu) buku literasi & $100 \%$ \\
\hline
\end{tabular}




\begin{tabular}{cc}
\hline Ajar & matematika dan \\
& 1 (satu) buku literasi \\
bahasa
\end{tabular}

\section{Simpulan dan saran}

Kegiatan pengabdian dalam skema Iptek bagi Masyarakat (IbM) ini dilaksanakan melalui serangkaian kegiatan yaitu : 1) Kegiatan Pelatihan Literasi dan Penelitian Pengembangan, 2) Pengembangan Buku Ajar yang dilakukan berdasarkan tahapan pengembangan model ADDIE yang merupakan singkatan dari Analysis, Design, Development, Implementation, and Evaluation.

Pada kegiatan pelatihan literasi dan penelitian pengembangan, guru-guru mendapatkan paparan materi dan berdiskusi dengan tim pengabdi sehingga guru-guru merasakan manfaat antara lain: 1) Meningkatnya pengetahuan dan pemahaman guru tentang literasi khususnya literasi matematika dan bahasa, 2) Meningkatnya kesadaran guru tentang pentingnya literasi bagi peserta didik, 3) Meningkatnya pengetahuan dan pemahaman guru tentang model penelitian pengembangan khususnya model ADDIE, 4) Meningkatnya pengetahuan dan pemahaman guru tentang teknik penulisan buku

Pada kegiatan pengembangan buku ajar, guru terlibat langsung dalam proses sehingga: 1) Guru termotivasi dalam menulis bahan ajar yang sesuai dengan latar belakang sosial budaya dan kemampuan peserta didiknya, 2) Kemampuan guru dalam mengembangkan materi pembelajaran yang diampu meningkat, 3) Kreatifitas guru terasah karena guru membuat bahan bacaan bagi peserta didiknya, memaparkan materi dengan cara yang mudah dipahami serta membuat sendiri permasalahanpermasalahan yang disajikan dalam buku ajar, 4) Guru memiliki pengalaman mengimplementasikan model pembelajaran inovatif dalam hal ini Pembelajaran Berbasis Masalah (Problem Based Learning)

Melihat manfaat yang dirasakan oleh para guru khususnya yang berada di sekolah mitra dapat dikatakan bahwa keberlanjutan kegiatan program pengabdian masyarakat merupakan hal yang sangat penting, oleh karena itu : 1) Dukungan dan komitmen pemerintah dalam menyediakan dana pendamping bagi peningkatan keterampilan guru sangat diperlukan, 2) Dinas pendidikan dapat menjalin kerjasama dengan pihak LPTK agar terjadi hubungan yang dinamis dan menguntungkan kedua belah pihak, 3) Sekolah dapat mengupayakan peningkatan kompetensi guru melalui kegiatan pelatihan yang dislenggarakan secara mandiri maupun kerjasama dengan pihak yang terkait misalnya dengan LPTK di lokasi yang berdekatan.

\section{Daftar Pustaka}

Freudenthal, H. (1991). 'Revisiting Mathematics Education:China Lectures'. Dordrecht, The Netherland : Kluwer Academics Publisher.

Gravemeijer,K.P.E. (1994). Developing Realistic Mathematics Education. Utrecht : Freudenthal Institute.

Hayat, dkk. (2010). Mutu Pendidikan. Jakarta. Bumi Aksara.

Khikmiyah, Fatimatul (2016). Pengembangan buku ajar Literasi Matematika Untuk Pembelajaran di SMP. Jurnal Silogime:Kajian Ilmu Matematika dan Pembelajarannya Vol 1 No. 2 Desember. ISSN : 2527-6182

Margono, S.(2010). Metodelogi Penelitian Pendidikan, Jakarta:Rineka Cipta

Meyer, Katrina A. (2003). "Face-to-face versus threaded discussions: The role of time and higher-order thinking" dalam Journal of Asynchronous Learning Networks.7(3): 55-65.

Moedjiono, Dimyati Moh, dkk. (1992). Strategi Belajar Mengajar. Jakarta : Depdiknas.

OECD. (2013). PISA 2012 Assessment And Analytical Framework:Mathematics, Reading, Science, Problem Solving and Financial Literacy, OECD Publishing.

Saputro, Suprihadi, dkk. (2000). Strategi Pembelajaran. Jakarta : Depdiknas 